\title{
Lipopolysaccharide impairs amyloid beta efflux from brain: altered vascular sequestration, cerebrospinal fluid reabsorption, peripheral clearance and transporter function at the blood-brain barrier
}

Michelle A Erickson ${ }^{1,2}$, Pehr E Hartvigson², Yoichi Morofuji ${ }^{2,3}$, Joshua B Owen ${ }^{2,3}$, D Allan Butterfield ${ }^{4}$ and William A Banks ${ }^{2,3^{*}}$

\begin{abstract}
Background: Defects in the low density lipoprotein receptor-related protein-1 (LRP-1) and p-glycoprotein (Pgp) clearance of amyloid beta (AB) from brain are thought to contribute to Alzheimer's disease (AD). We have recently shown that induction of systemic inflammation by lipopolysaccharide (LPS) results in impaired efflux of A $\beta$ from the brain. The same treatment also impairs Pgp function. Here, our aim is to determine which physiological routes of $A \beta$ clearance are affected following systemic inflammation, including those relying on LRP-1 and Pgp function at the blood-brain barrier.

Methods: CD-1 mice aged between 6 and 8 weeks were treated with 3 intraperitoneal injections of $3 \mathrm{mg} / \mathrm{kg}$ LPS at 0,6 , and 24 hours and studied at 28 hours. ${ }^{125}$ I-A $\beta_{1-42}$ or ${ }^{125}$-alpha-2-macroglobulin injected into the lateral ventricle of the brain (intracerebroventricular (ICV)) or into the jugular vein (intravenous (IV)) was used to quantify LRP-1-dependent partitioning between the brain vasculature and parenchyma and peripheral clearance, respectively. Disappearance of ICV-injected ${ }^{14} \mathrm{C}$-inulin from brain was measured to quantify bulk flow of cerebrospinal fluid (CSF). Brain microvascular protein expression of LRP-1 and Pgp was measured by immunoblotting. Endothelial cell localization of LRP-1 was measured by immunofluorescence microscopy. Oxidative modifications to LRP-1 at the brain microvasculature were measured by immunoprecipitation of LRP-1 followed by immunoblotting for 4-hydroxynonenal and 3-nitrotyrosine.

Results: We found that LPS: caused an LRP-1-dependent redistribution of ICV-injected A $\beta$ from brain parenchyma to brain vasculature and decreased entry into blood; impaired peripheral clearance of IV-injected A ; inhibited reabsorption of CSF; did not significantly alter brain microvascular protein levels of LRP-1 or Pgp, or oxidative modifications to LRP-1; and downregulated LRP-1 protein levels and caused LRP-1 mislocalization in cultured brain endothelial cells.

(Continued on next page)
\end{abstract}

\footnotetext{
* Correspondence: wabanks1@uw.edu

${ }^{2}$ GRECC, Veterans Affairs Puget Sound Health Care System, $1600 \mathrm{~S}$.

Columbian Way, Seattle, WA 98108, USA

${ }^{3}$ Division of Gerontology and Geriatric Medicine, Department of Internal

Medicine, University of Washington School of Medicine, Bldg. 1, Rm. 810A,

1660 Columbian Way, Seattle, WA 98108, USA

Full list of author information is available at the end of the article
} 
(Continued from previous page)

Conclusions: These results suggest that LRP-1 undergoes complex functional regulation following systemic inflammation which may depend on cell type, subcellular location, and post-translational modifications. Our findings that systemic inflammation causes deficits in both $A \beta$ transport and bulk flow like those observed in $A D$ indicate that inflammation could induce and promote the disease.

Keywords: Alzheimer's disease, amyloid beta, blood-brain barrier, inflammation, lipopolysaccharide, LRP1, Pgp, $A B C B 1, M D R 1$, cerebrospinal fluid

\section{Background}

Alzheimer's disease (AD) is the most common form of senile dementia [1] and according to the amyloid cascade hypothesis results from the accumulation of amyloid beta $(A \beta)$ in the brain [2]. The neurovascular hypothesis of Zlokovic states that a critical pathological event driving $A \beta$ accumulation in brain is the reduced clearance of $A \beta$ from brain across the blood-brain barrier (BBB) [3]. A large body of work from multiple groups has shown that the low-density lipoprotein receptor-related protein-1 (LRP-1) transports A $\beta$ across the $\mathrm{BBB}$ in the brain-to-blood direction, and becomes deficient in AD [4-8]. Evidence for LRP-1 deficiency includes the correlation of LRP-1 levels with impairment of $\mathrm{A} \beta$ efflux in rodent models of AD [4], LRP-1 downregulation in brain microvasculature of patients with $\mathrm{AD}$ [8], and oxidative modification of LRP-1 in AD hippocampus [9]. Growing evidence also supports a role of a second efflux transporter, $\mathrm{p}$-glycoprotein (Pgp), in A $\beta$ efflux across the BBB [10]. Similar to LRP-1, results suggest that Pgp dysfunction also occurs in $\mathrm{AD}[11,12]$. Despite data supporting a deficiency in $A \beta$ transport in $\mathrm{AD}$, little is known about the mechanisms that could initiate or sustain these transport deficiencies in disease progression.

Two other processes which are thought to contribute to the level of $A \beta$ in brain are clearance through bulk flow of cerebrospinal fluid (CSF), and clearance of $A \beta$ from the periphery. Bulk flow denotes the reabsorption of CSF into peripheral compartments, including the systemic circulation [13]. Inhibition of CSF turnover occurs in $\mathrm{AD}$, and is thought to contribute to buildup of potential toxins, including $A \beta$, in the $A D$ brain [14]. Furthermore, reduction of $A \beta$ in brain restores bulk flow in an AD mouse model [15]. Therefore, deficiency of CSF turnover reflects an important pathophysiological consideration in AD. Multiple groups have shown that peripheral clearance of $A \beta$ is important in regulating $A \beta$ levels in brain and may decrease in $A D$. This clearance occurs primarily through the liver and kidney [16], and LRP-1 has been identified as a primary transporter for uptake of A $\beta$ by liver [17]. Two potential mechanisms could explain how decreased clearance of $\mathrm{A} \beta$ from blood contributes to accumulation in brain. First, the receptor for advanced glycation endproducts (RAGE) has been identified as an influx transporter for $A \beta$ [18]. Therefore, decreases in peripheral clearance of $\mathrm{A} \beta$ would promote entry into the brain. Second, decreased $A \beta$ clearance from the periphery is associated with impaired efflux [19]. The mechanism governing this phenomenon is presently unclear, but could be attributed to concentration gradients or endothelial dysfunction due to RAGE activation [20]. Understanding the mechanisms that contribute to impairment of $\mathrm{BBB}$ efflux, CSF bulk flow, and reduced peripheral clearance of $\mathrm{A} \beta$ in $\mathrm{AD}$ may provide clues for the important early stages of $\mathrm{AD}$ pathogenesis.

Inflammation and oxidative stress in the brain are concurrent with $\mathrm{AD}$ and roles for each in the pathogenesis of $\mathrm{AD}$ have been proposed. $\mathrm{A} \beta$ causes inflammation in the brain through Toll-like receptor and complement activation [21-23]. Elevated levels of proinflammatory cytokines and acute phase proteins are localized around $\mathrm{A} \beta$ plaques in $\mathrm{AD}[21]$, suggesting that the $\mathrm{AD}$ brain is in a chronic proinflammatory state. Oligomeric $A \beta_{1-42}$ can also cause oxidative stress by integrating into membranes and catalytically generating the lipid peroxidation product, 4-hydroxynonenal (HNE) [24], and through activation of the ROS-generating enzyme NADPH oxidase in microglia [25]. In addition to causal roles of $A \beta$ initiating neuroinflammation and oxidative stress, inflammation and/or oxidative stress can themselves cause $\mathrm{A} \beta$ accumulation in the brain. The amyloid precursor protein, from which $A \beta$ is cleaved, is transcriptionally regulated similarly to heat shock proteins and is responsive to the proinflammatory cytokine IL-1 [26]. Others have shown that lipopolysaccharide (LPS)-induced inflammation increases $A \beta$ accumulation and deposition in brain $[27,28]$. Oxidative stress upregulates proteins involved in $A \beta$ production, such as presenilin 1 [29]. Because $A \beta$ is present in brain under physiological conditions and upregulated by stressors, some have postulated that $A \beta$ plays important roles in the stress response. Modest, transient upregulation of $A \beta$ in the brain may serve as an antioxidant defense [30] and promote clearance of damaged cells in the brain by microglia [31]. Under 
severe or chronic conditions of cellular stress, it is therefore feasible that $A \beta$ accumulation could transition to pathological levels, resulting in formation of toxic oligomers that drive the $\mathrm{AD}$ process. This warrants further investigation into mechanisms by which inflammation and oxidative stress contribute to $\mathrm{BBB}$ efflux of $\mathrm{A} \beta$.

Evidence supports that induction of systemic inflammation by the proinflammatory molecule LPS alters both LRP-1 and Pgp at the BBB. Our group has previously reported that peripheral administration of LPS inhibits $A \beta$ efflux transport out of the brain [32]. LPS also is known to increase LRP-1 proteolytic processing in macrophages and neurons [33,34]. Because increased oxidative stress occurs in brains with systemic inflammation [35] and increased oxidative modifications on LRP1 are found in AD [9], it is also possible that oxidative modifications on LRP-1 contribute to its dysfunction following LPS. Many groups have observed decreased functional Pgp in inflammatory models [36-38], including the regimen shown to impair $A \beta$ efflux [7]. Because LRP-1 and Pgp are located at the abluminal and luminal membranes of the brain endothelial cell respectively, it has been proposed that LRP-1 facilitates the initial uptake of $A \beta$ from the brain interstitial fluid, followed by Pgp pumping $A \beta$ out of the endothelial cell into the blood [11]. Pgp may also regulate $A \beta$ levels in brain by restricting the entry of circulating $A \beta[39]$.

In this study our goal was to investigate mechanisms by which LPS alters A $\beta$ transport out of the brain. To do this, we first measured LPS-induced changes in partitioning between the neurovasculature and parenchyma of ${ }^{125}$ I-labeled murine $A \beta_{1-42}$ or the LRP-1 ligand alpha2 -macroglobulin (a2M) injected in the lateral ventricle of the brain. We then measured effects of LPS on peripheral clearance of $A \beta$, effects on CSF bulk flow, and changes in microvascular LRP-1 and Pgp. Our findings highlight that multiple routes of $A \beta$ clearance are impaired by LPS, and therefore may have a synergistic effect on $A \beta$ accumulation in brain.

\section{Methods}

\section{Animal use and treatment regimens}

All animal protocols were performed in an Association for Assessment and Accreditation of Laboratory Animal Care accredited facility and approved by the animal committee of the VA and St Louis University Medical Centers. Male CD-1 mice were purchased from Charles River and kept on a 12/12 hour light/dark cycle with food and water freely available. Mice at 6-8 weeks of age were treated with 3 intraperitoneal (IP) injections of $3 \mathrm{mg} / \mathrm{kg}$ LPS from Salmonella typhimurium (Sigma, St. Louis, MO, USA) dissolved in sterile normal saline over a 24-hour period as previously described [32]. Briefly, the first injection was given in the morning, and the second and third injections were given at 6 and 24 hours following the first injection, respectively. All mice were studied at 28 hours following the first injection. Mice given this injection regimen displayed overt sickness behavior and weight loss. No mice died as a result of this treatment regimen. A total of 225 mice were used in this study: 90 were used for detection of oxidative modifications to LRP-1 and Pgp measurement, 30 for LRP-1 measurement, 44 for measurement of $\mathrm{A} \beta$ and a2M vascular sequestration, 20 for CSF bulk flow measurement, 21 for measurement of peripheral $A \beta$ clearance, and 20 for primary endothelial cell culture.

\section{lodination of $A \beta$, a2M, and albumin}

Murine $A \beta_{1-42}$ was purchased from Bachem (Torrance, CA, USA) and bovine serum albumin (BSA) and human a2M from Sigma (St. Louis, MO, USA). Lyophilized A $\beta$ was resuspended at a concentration of $1 \mathrm{mg} / \mathrm{ml}$ in $0.1 \mathrm{M}$ ammonium hydroxide to prevent aggregation, aliquoted, and stored frozen at $-80{ }^{\circ} \mathrm{C}$ for up to 3 months. Lyophilized a2M was resuspended in water at a $1 \mathrm{mg} / \mathrm{ml}$ concentration and stored at $-20{ }^{\circ} \mathrm{C}$. Activation of a2M was done by incubating in a final concentration of $0.2 \mathrm{M}$ methylamine overnight at room temperature as described previously [40]. Using the chloramine-T method [41], $5 \mu \mathrm{g}$ of $\mathrm{A} \beta$, albumin, or a2M was labeled with $0.5 \mathrm{mCi}{ }^{125} \mathrm{I}$ or ${ }^{131} \mathrm{I}$ (Perkin Elmer, Waltham, MA, USA), and separated from free ${ }^{125} \mathrm{I}$ on a Sephadex G-10 column (Sigma, St. Louis, MO, USA) to yield radioactively labeled $A \beta$ (I-A $\beta$ ), albumin (I-albumin), or a2M $(\mathrm{I}-\mathrm{a} 2 \mathrm{M})$. To assess stability of $\mathrm{I}-\mathrm{A} \beta$ and I-albumin, an aliquot of the labeled peptide fraction was precipitated in $15 \%$ trichloroacetic acid. All iodinated proteins consistently showed greater than $95 \%$ activity in the precipitate, and I-A $\beta$ and I-a2M was always used within 24 hours of radioactive labeling. We have found that this method of $A \beta$ labeling shows specificity for LRP-1dependent BBB efflux from brain [7].

\section{Measurement of inulin efflux}

Inulin is not transported across the BBB and lacks binding sites in brain tissue [4]. Therefore, any efflux of inulin from brain would represent a bulk flow route. To measure inulin efflux, ${ }^{14} \mathrm{C}$-inulin (Perkin Elmer, Waltham, MA, USA) was diluted to a concentration of $1 \times 10^{6}$ $\mathrm{CPM} / \mu \mathrm{l}$ in BSA/lactated Ringer's solution; saline or LPStreated mice were anesthetized with $40 \%$ urethane, and $1 \mu \mathrm{l}{ }^{14} \mathrm{C}$-inulin was injected into the lateral ventricle of the brain (intracerebroventricular (ICV)) by reflecting the scalp and drilling a hole $1 \mathrm{~mm}$ lateral and $0.5 \mathrm{~mm}$ posterior to the bregma, followed by injection at a depth of $2.5 \mathrm{~mm}$ using a $26 \mathrm{~g}$ Hamilton syringe. Venous blood and brains were collected 10 minutes post-injection (t10). To account for central nervous system (CNS). 
distribution of ${ }^{14} \mathrm{C}$-inulin, an identical treatment group was overdosed with urethane, and ${ }^{14} \mathrm{C}$-inulin was injected ICV 10 minutes post-mortem (t0). Only brains were collected for this group. For quenching normalization of brains, $1 \mu \mathrm{l}$ of injectate (injection check) was added in triplicate to a matrix of solubilized brain in liquid scintillation cocktail. Injection checks for serum were in liquid scintillation counter (LSC) cocktail. Radioactivity in solubilized brain and $50 \mu \mathrm{l}$ of serum was measured using a Packard Tri-carb LSC. Brain efflux was calculated by first determining the percent of injected material remaining in brain in $\mathrm{t} 10$ and to groups:

$$
\begin{aligned}
\% \text { Inj } / \text { brain }= & 100(\text { CPM in brain } \\
& / \text { CPM injection check })
\end{aligned}
$$

Delta values were calculated by subtracting individual values of \%Inj/brain for each t10 mouse from the average \%Inj/brain of each to group:

$$
\begin{aligned}
\text { Delta\%Inj } / \text { brain } & =(\text { Average\%Inj } / \text { brain t0 }) \\
& -(\% \text { Inj } / \text { brain } 10)
\end{aligned}
$$

Appearance of ICV-injected material in serum was calculated by determining the percent of injected material per microliter:

$$
\begin{aligned}
\% \text { Inj } / \mu l= & 100(C P M \text { in serum } \\
& / C P M \text { injection check }) / 50 \mu l
\end{aligned}
$$

\section{Measurement of vascular sequestration of $A \beta$ and a2M}

Vascular sequestration of ICV-injected I-A $\beta$ or I-a2M was measured using a modified version of the capillary depletion method [42]. I-A $\beta$ or I-a2M was diluted in BSA/lactated Ringer's solution to a concentration of $2 \times 10^{5} \mathrm{CPM} / \mu \mathrm{l}$. As described under 'Measurement of inulin efflux', $1 \mu \mathrm{l}$ I-A $\beta$ or I-a2M was injected in the lateral ventricle of the brain. Blood from the jugular vein and brains were collected at 10 minutes post-injection, and brains were immediately put in ice-cold vascular depletion buffer (10 mM HEPES, $141 \mathrm{mM} \mathrm{NaCl}, 4 \mathrm{mM}$ $\mathrm{KCl}, 2.8 \mathrm{mM} \mathrm{CaCl}, 1 \mathrm{mM} \mathrm{MgSO}, 1 \mathrm{mM} \mathrm{NaH} \mathrm{PO}_{4}$, $10 \mathrm{mM}$ D-glucose), and stored on ice until processing. Blood was allowed to clot at room temperature, and then centrifuged at 5,000 $\mathrm{g}$ to separate the serum from blood cells. Brains were homogenized with 6-8 passes of a Teflon pestle, and homogenates diluted in an equal volume of $40 \%$ ice-cold dextran (Sigma, St. Louis, MO, USA). Homogenates were centrifuged for 20 minutes at $3,500 \mathrm{~g}$ at $4{ }^{\circ} \mathrm{C}$, and the parenchymal layer and dextran interface were removed and transferred to a separate tube. The remaining vascular pellet, as well as the dextran/parenchymal layers, were then counted separately in a gamma counter. Data for activity present in the vascular or parenchymal fractions were expressed as \% total CPM:

$$
\begin{aligned}
& \text { \% Total CPM } \\
& =\text { CPM in parenchymal or vascular fraction } \\
& \quad /(C P M \text { in vascular fraction } \\
& \quad+\text { CPM in parenchymal fraction }) * 100
\end{aligned}
$$

\section{Measurement of $A \beta$ uptake by liver and kidney, and clearance in serum}

In BSA/lactated Ringer's solution $3 \times 10^{5} \mathrm{CPM}$ of ${ }^{131} \mathrm{I}$ $A \beta$ and ${ }^{125} \mathrm{I}$-albumin were prepared and injected together into the jugular vein of mice treated with LPS or saline. The liver, the left kidney, and blood from the carotid artery were collected at $1,2,5,10$, and 20 minutes. Blood was allowed to clot, spun at 5,000 g to separate serum from blood cells, and $50 \mu \mathrm{l}$ serum was counted along with harvested tissues from liver and kidney in a gamma counter. The rate of I-A $\beta$ tissue uptake was determined using multiple-time regression analysis [43]. For this analysis, experimental clock time was reexpressed as exposure time to correct for clearance of IA $\beta$ from the blood. Exposure time was calculated from the formula:

$$
\text { Exposure time }=\left(\int_{0}^{t} C p t(t) d t\right) / C p t
$$

where $t$ equals experimental clock time, $\mathrm{Cp}$ represents the level of radioactivity in the serum over time and $\mathrm{Cpt}$ is the level of radioactivity in the serum at time $\mathrm{t}$. Tissue/serum ratios were then calculated from the following formula:

$$
\begin{aligned}
\text { Tissue } / \text { serum ratio }= & (\text { serum volume })(\text { tissue } C P M) \\
& /(\text { tissue weight })(\text { serum } C P M)
\end{aligned}
$$

To correct for alterations in vascular space and/or vascular permeability which occur with LPS administration, tissue/serum ratios for I-albumin were subtracted from those for I-A $\beta$. The corrected tissue/serum ratios were plotted against exposure time calculated for $A \beta$, and the unidirectional influx constant determined from the slope of the linear portion of the curve.

Serum clearance was calculated by plotting the log serum $\mathrm{CPM} / 50 \mu \mathrm{l}$ versus experimental clock time. The slope of this line is proportional to half-life by the equation:

$$
\text { Half - life in serum }=\log (2) /- \text { slope }
$$

\section{Microvessel isolation}

Isolation of brain microvessels from mice treated with saline or LPS was performed according to a modified 
protocol [44]. Briefly, three or ten brains (for western blotting and immunoprecipitation, respectively) were pooled per treatment group and homogenized in icecold DMEM + 0.5\% PMSF with 6-8 passes of a Teflon pestle, followed by filtration once through a $300 \mu \mathrm{m}$ nylon mesh, and twice through two $100 \mu \mathrm{m}$ nylon mesh filters. Filtrates were then mixed with an equal volume of cold 40\% dextran dissolved in DMEM, and centrifuged at $3,500 \mathrm{~g}$ for 30 minutes at $4{ }^{\circ} \mathrm{C}$. The upper parenchymal layer was removed and washed once with ice-cold PBS + protease inhibitor cocktail (Sigma, St. Louis, MO, USA), and stored at $-80{ }^{\circ} \mathrm{C}$ prior to protein extraction. The dextran gradient was discarded, and the microvessel pellet resuspended in DMEM. Suspended vessels were then poured onto a $25 \mu \mathrm{m}$ mesh and washed extensively with DMEM to remove cellular debris. Washed vessels were then removed from the mesh, checked for purity by light microscopy, and washed once with $\mathrm{PBS}+$ protease inhibitor cocktail. The washed microvascular pellet was then stored at $-80{ }^{\circ} \mathrm{C}$ prior to protein extraction. The typical microvascular protein yield for this procedure is approximately $10 \mu \mathrm{g}$ per mouse.

\section{Culture of primary human, mouse, and immortalized rat brain microvascular endothelial cells and treatment with LPS}

Primary human brain microvascular endothelial cells (HBECs) were purchased from Cell Systems (Kirkland, WA, USA) and cultured according to the company's instructions. Cells at passage 6 were used in this study. Immortalized rat brain endothelial cells (RBE4), a gift from Dr Pierre Couraud, were seeded on rat tail collagen in a type 1 coated tissue culture plate (TPP, Trasadingen, Switzerland and maintained in Ham's F10/ $\alpha$ medium 1:1 (Gibco, Invitrogen, St. Louis, MO, USA), 10\% fetal bovine serum, $1 \mathrm{ng} / \mathrm{ml}$ basic fibroblast growth factor (Sigma, St. Louis, MO, USA), $300 \mu \mathrm{g} / \mathrm{ml}$ geneticin (Gibco, St. Louis, MO, USA), and $50 \mu \mathrm{g} / \mathrm{ml}$ gentamicin (Sigma, St. Louis, MO, USA). All cells were maintained at $37{ }^{\circ} \mathrm{C}$ in a humidified atmosphere of $5 \% \mathrm{CO}_{2}$ and $95 \%$ air. Culture medium was changed twice a week, and endothelial cells at passages 7 were used in this study. Primary cultures of mouse brain capillary endothelial cells (MBECs) were isolated from 8-week-old CD1 mice according to published protocols [45] with modifications. MBECs were seeded on dishes (flasks, plates) coated with collagen type IV and fibronectin (both $0.1 \mathrm{mg} / \mathrm{ml})$. MBEC cultures were maintained in DMEM/ F12 supplemented with $10 \%$ plasma-derived serum (PDS, Animal Technologies, Inc., Tyler, TX, USA), 1\% GlutaMAX supplement (Gibco, St. Louis, MO, USA), basic fibroblast growth factor (bFGF, Roche Applied Sciences, Indianapolis, IN, USA, $1 \mathrm{ng} / \mathrm{ml}$ ), heparin $(100 \mu \mathrm{g} / \mathrm{ml})$, insulin $(5 \mu \mathrm{g} / \mathrm{ml})$, transferrin $(5 \mu \mathrm{g} / \mathrm{ml})$, sodium selenite $(5 \mathrm{ng} / \mathrm{ml})$ (insulin-transferrin-sodium selenite media supplement), and gentamicin $(50 \mu \mathrm{g} / \mathrm{ml})$ at $37{ }^{\circ} \mathrm{C}$ with a humidified atmosphere of $5 \% \mathrm{CO}_{2} / 95 \%$ air; pericytes were eliminated from the culture by including puromycin $(4 \mu \mathrm{g} / \mathrm{ml})$ [46] in this medium (MBEC medium I). Red blood cells, cell debris, and nonadherent cells were removed 24 hours after plating by washing with medium. On the third day, the cells received a new medium which contained all components of MBEC medium I except puromycin (MBEC medium II). When the cultures reached $80 \%$ confluency (fifth day in vitro), the purified endothelial cells were passaged by brief treatment with $0.25 \%$ Trypsin-EDTA (Gibco, St. Louis, MO, USA) solution, and used to construct in vitro $\mathrm{BBB}$ models on transwell inserts (Corning Inc., Corning, NY, USA). All cells were treated with $0.1 \mathrm{mg} /$ $\mathrm{ml}$ LPS dissolved in culture medium for 4 hours (HBEC) or 24 hours (MBEC and RBE4). Fresh culture medium was used as a control. Cells were then extracted for protein or fixed for immunostaining.

\section{Protein extraction and immunoprecipitation of LRP-1}

Protein from washed cells, isolated brain microvessels, and vascular-depleted brain parenchyma were extracted in ice-cold lysis buffer (PBS plus 1\% NP-40, $1 \mathrm{mM}$ PMSF, and protease inhibitor cocktail) by scraping (cells) or homogenization (tissues) followed by shaking vigorously for 30 minutes at $4{ }^{\circ} \mathrm{C}$. Extracts were then centrifuged at $20,000 \mathrm{~g}$ for 10 minutes at $4{ }^{\circ} \mathrm{C}$, and supernatants were used for protein analysis. Protein was quantified in all extracts by bicinchoninic acid assay (Thermo Scientific, Rockford, IL, USA). Immunoprecipitation of LRP-1 from brain microvessel extracts was performed using a modified protocol which has been described previously [9]. Briefly, $75 \mu \mathrm{g}$ of microvessel extract was diluted in $500 \mu \mathrm{l}$ IP buffer $(0.05 \%$ NP-40 plus protease inhibitor cocktail in $\mathrm{PBS}$ ), and precleared by incubating with $50 \mu \mathrm{l}$ washed protein $\mathrm{A} / \mathrm{G}$ sepharose beads (Calbiochem, Billerica, MA, USA) for 90 minutes at $4{ }^{\circ} \mathrm{C}$. The precleared supernatant was then incubated overnight at $4{ }^{\circ} \mathrm{C}$ with $10 \mu \mathrm{g}$ anti-LRP-1 rabbit monoclonal primary antibody (Epitomics, Burlingame, CA, USA), and the antigen-antibody complexes immunoprecipitated by incubating with $50 \mu \mathrm{l}$ washed protein A/G beads for 1 hour at $4{ }^{\circ} \mathrm{C}$. The beads were then washed 5 times in IP buffer, and the antigen-antibody complex eluted by adding $25 \mu \mathrm{l}$ buffer for SDS-PAGE $(1 \times \mathrm{LDS}$, $1 \times \mathrm{dTT}$, Invitrogen, Grand Island, NY, USA) and heating at $70{ }^{\circ} \mathrm{C}$ for 10 minutes.

\section{Immunoblot analysis}

For analysis of 3-nitrotyrosine (3-NT) and HNE modified LRP-1, $5 \mu \mathrm{l}$ of immunoprecipitated microvascular or parenchymal LRP-1 from saline or LPS-treated mice was 
resolved in duplicate on a 4-12\% Bis-Tris gel (Invitrogen, Grand Island, NY, USA). Protein was then transferred to nitrocellulose membranes using an iBlot transfer device (Invitrogen, Grand Island, NY, USA), washed 5 minutes in PBS-T, and blocked for 1 hour in $5 \%$ milk dissolved in PBS-T. All antibody incubations were done for 1 hour at room temperature, except for Pgp which was done at $4{ }^{\circ} \mathrm{C}$ overnight. One membrane was probed with anti-HNE mouse monoclonal antibody ( $\mathrm{R}$ and D systems, Minneapolis, MN, USA; $2 \mu \mathrm{g} / \mathrm{ml}$ ) and the other membrane probed with anti-3-NT mouse monoclonal antibody (Millipore, St. Charles, MO, USA; $2 \mu \mathrm{g} / \mathrm{ml})$. Both membranes were then washed, and probed with anti-mouse secondary antibody conjugated to horseradish peroxidase (Santa Cruz Biotechnology, Inc., Santa Cruz, CA, USA; 1:5,000). Following band visualization, both blots were stripped and confirmed for absence of signal. Blots were then re-probed with an anti-LRP-1 antibody which recognizes the small subunit (Epitomics Burlingame, CA, USA; $0.2 \mu \mathrm{g} / \mathrm{ml}$ ), washed, and probed with anti-rabbit secondary (Santa Cruz Biotechnology, Inc., Santa Cruz, CA, USA; 1:10,000). Band intensities for HNE and 3-NT were then normalized for LRP-1 signal. For analysis of LRP-1 in isolated microvessels, $15 \mu \mathrm{g}$ were loaded on a 3-8\% Tris-acetate gel (Invitrogen, Grand Island, NY, USA), and transferred onto a nitrocellulose membrane. Prior to probing for LRP-1, the blot was stained with SYPRO ruby (Invitrogen, Grand Island, NY, USA), and protein bands were quantified under UV exposure for normalization, as described previously. The blot was then blocked, and probed with anti-LRP-1 antibody which recognizes the large subunit ( $2 \mu \mathrm{g} / \mathrm{ml} 1$ hour at room temperature), followed by probing with secondary anti-rabbit $(1: 5,000)$. The same blot was then re-probed for the small subunit of LRP-1 using the antibody from Epitomics $(0.1 \mu \mathrm{g} / \mathrm{ml})$, followed by anti-rabbit secondary. Immunoblotting of HBEC lysates was done using the same method for isolated brain microvessels, with the following modifications: $8 \mu \mathrm{g}$ was used for loading, blots were only probed for the small subunit of LRP-1, and bands were normalized to gamma-tubulin (Santa Cruz Biotechnology, Inc., Santa Cruz, CA, USA; $1 \mu \mathrm{g} / \mathrm{ml}$ ). Immunodetection of Pgp was done in microvascular extracts by loading $3 \mu \mathrm{g}$ of protein on a $4-12 \%$ Bis-Tris gel under nonreducing conditions. The lower half of the blot was stained with SYPRO ruby, and the upper half probed for Pgp (primary: C219, Covance, Princeton, NJ, USA; $1 \mu \mathrm{g} / \mathrm{ml}$ in $2 \%$ milk, secondary: Santa Cruz; 1:5,000). As a significant hook effect has been reported for Pgp [47], it was confirmed that our protein loading conditions fell within linear range of antibody signal for Pgp. All immunoreactive bands were visualized using West Pico chemiluminescent substrate (Thermo Scientific, Rockford, IL, USA) and all images were captured using an ImageQuant LAS4000 CCD imaging system (GE Life Sciences, Piscataway, NJ, USA) except for HBEC blots, which were captured on film. Densitometric analysis was done using IQTL software (GE Life Sciences, Piscataway, NJ, USA).

\section{Dot blot analysis}

RBE4 lysates were diluted to a final concentration of $4 \mu \mathrm{g} / \mathrm{ml}$ in PBS, and $1 \mu \mathrm{g}$ of protein was loaded onto a nitrocellulose membrane in duplicate using a Bio-dot apparatus (BioRad, Hercules, CA, USA). Membranes were then probed for the small subunit of LRP-1 and analyzed by densitometry as described above. The antibody used for detection is specific for LRP-1, and shows no signal in the PEA-13 knockout cell line [47].

\section{Immunocytochemistry}

MBECs grown on Transwell inserts were washed in PBS and fixed with $4 \%$ PFA for 10 minutes at $4{ }^{\circ} \mathrm{C}$. Cells were permeabilized with $0.1 \%$ TRITON-X100, blocked with $5 \%$ BSA and then incubated with anti-LRP1 rabbit monoclonal antibody (Epitomics, Burlingame, CA, USA) and anti-ZO-1 rat monoclonal antibody (Millipore, St. Charles, MO, USA) followed by incubation with corresponding Alexa Flour-488 or Alexa Flour-568 conjugated secondary antibody (Invitrogen, Grand Island, NY, USA ). Inserts were mounted in antifade media containing DAPI (nuclear) counterstain and photographed with a Nikon ECLIPSE E800 fluorescence microscope.

\section{Statistical analysis}

All statistical analysis was done using Prism 5 software (GraphPad Inc, San Diego, CA, USA). Data from liver and kidney uptake as well as serum clearance were analyzed by linear regression, and the remaining data were analyzed by two-tailed Student's $t$-tests. Data are shown as mean $+/-$ SEM. In all figures, ${ }^{*} P<0.05, * * P<0.01$, and ${ }^{* * *} P<0.001$ compared to saline.

\section{Results}

\section{Effects of LPS on vascular sequestration of $A \beta$ and a2M}

To characterize the defect in $A \beta$ transport by brain vasculature, the method of capillary depletion was applied which is routinely used to determine whether circulating compounds are sequestered by brain endothelial cells [42]. In this case, however, it was used to determine whether ICV-injected I-A $\beta$ showed significant changes in partitioning between the brain capillary and parenchymal compartments. We reasoned that decreased vascular partitioning of $A \beta$ would indicate decreased binding/ internalization at the abluminal surface, whereas increased vascular partitioning would indicate a postinternalization defect, that is, in the intracellular transport and luminal efflux phases. To establish whether our 


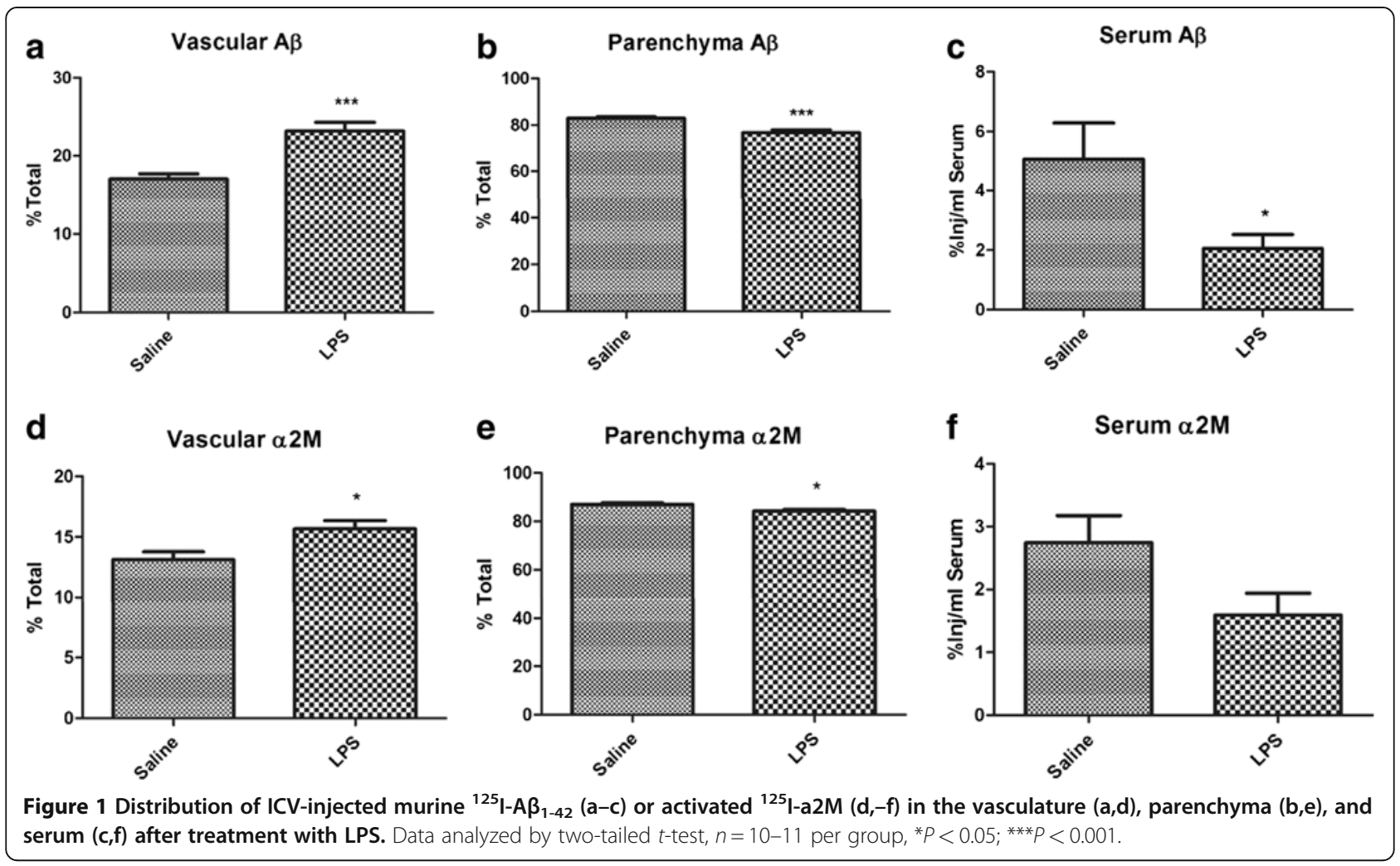

results reflected an LRP-1-dependent process, the same study was repeated with the LRP-1 ligand a2M. Figure 1 shows that LPS treatment significantly shifted brain distribution of $\mathrm{I}-\mathrm{A} \beta$ and $\mathrm{I}-\mathrm{a} 2 \mathrm{M}$ from the parenchymal compartment to the vascular compartment (Figure 1a,b; Figure $1 \mathrm{~d}, \mathrm{e})$, consistent with an LRP-1-dependent postbinding inhibition of $A \beta$ efflux. To confirm that this was associated with impaired $A \beta$ efflux, venous blood was
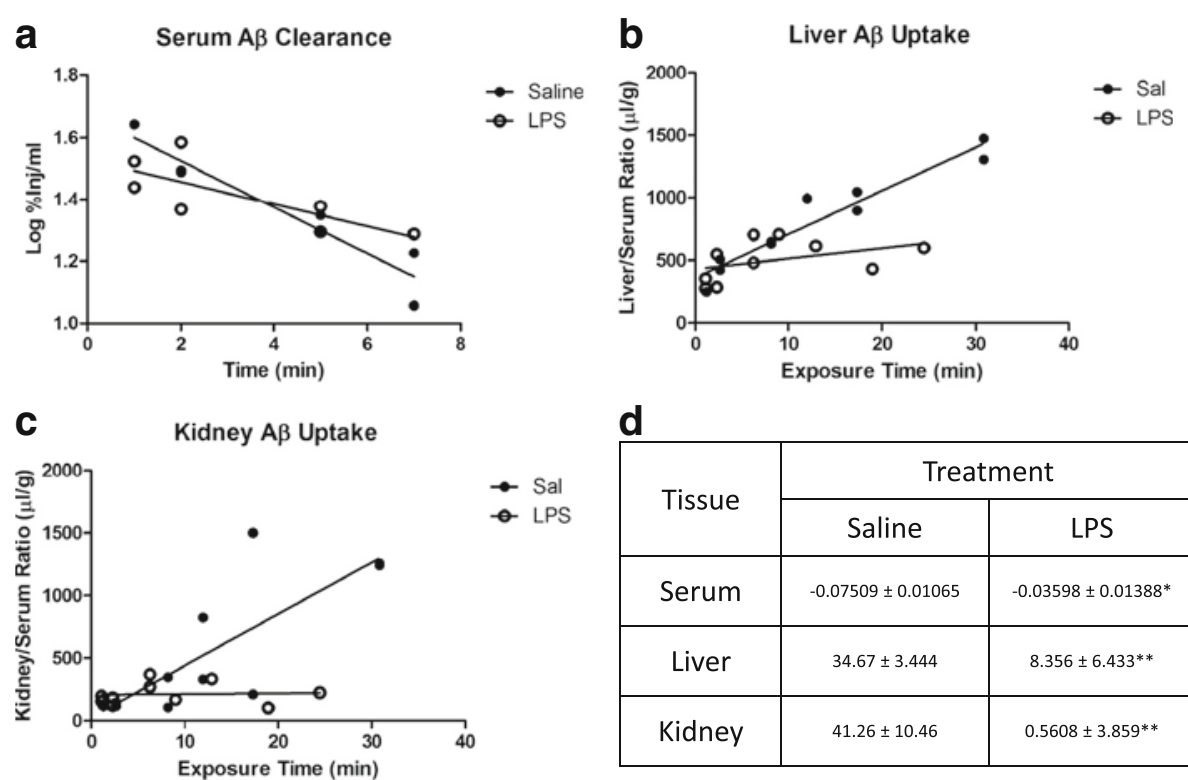

d

\begin{tabular}{|c|c|c|}
\hline \multirow{2}{*}{ Tissue } & \multicolumn{2}{|c|}{ Treatment } \\
\cline { 2 - 3 } & Saline & LPS \\
\hline Serum & $-0.07509 \pm 0.01065$ & $-0.03598 \pm 0.01388^{*}$ \\
\hline Liver & $34.67 \pm 3.444$ & $8.356 \pm 6.433^{* *}$ \\
\hline Kidney & $41.26 \pm 10.46$ & $0.5608 \pm 3.859 * *$ \\
\hline
\end{tabular}

Figure 2 Peripheral clearance of murine ${ }^{125} \mathrm{I}-\mathrm{A} \beta_{1-42}$ from blood (a), and uptake by liver (b) or kidney (c) following LPS. Clearance rate (\%lnj/ml-min) of $A \beta$ from serum and unidirectional influx rates for liver and kidney ( $\mu / \mathrm{g}-\mathrm{min})$ are shown in (d). Data analyzed by linear regression analysis, $n=7-10$ per group, ${ }^{*} P<0.05,{ }^{* *} P<0.01$. 
also collected from these mice just prior to decapitation. I-A $\beta$ in serum was significantly decreased with LPS and $\mathrm{I}-\mathrm{a} 2 \mathrm{M}$ showed a decreased trend $(\mathrm{p}=0.0538$; Figure 1c and $f$ ), supporting our previous findings that $A \beta$ efflux from brain is inhibited by systemic inflammation [32].

\section{LPS effects on clearance of $A \beta$ in the periphery}

Previous studies have shown that $A \beta$ in the circulation is cleared primarily by the liver and less so by the kidneys [16]. Because alterations in peripheral clearance would affect the serum levels of I-A $\beta$ shown in Figure 1, we determined the effect of LPS on A $\beta$ clearance from serum by liver and kidney. Figure 2a shows that clearance of I-A $\beta$ from serum is reduced with LPS treatment (half-life increased from 4 minutes for saline to $8.4 \mathrm{~min}$ utes for LPS), and this is coupled with a significantly decreased unidirectional influx rate of $A \beta$ into liver (Figure $2 \mathrm{~b}, \mathrm{Ki}=34.67 \pm 3.444$ and $8.356 \pm 6.433 \mu \mathrm{l} / \mathrm{g}$-min saline and LPS, respectively) and kidney (Figure $2 \mathrm{c}, \mathrm{Ki}=$ $41.26 \pm 10.46$ and $0.5608 \pm 3.859 \mu \mathrm{l} / \mathrm{g}$-min saline and LPS, respectively). Therefore, serum $A \beta$ levels shown in Figure $1 \mathrm{c}$ underestimate the magnitude of efflux impairment by LPS.

\section{Effects of LPS on CSF bulk flow}

In addition to saturable efflux across the $\mathrm{BBB}, \mathrm{A} \beta$ clearance from brain through bulk flow of CSF partially contributes to our measures of total $A \beta$ efflux. To test the effects of LPS on CSF bulk flow, we measured brain efflux of the bulk flow marker inulin [4]. Figure 3a shows disappearance of ${ }^{14} \mathrm{C}$-inulin from brain after 10 minutes, corrected for its CNS distribution at time zero. Therefore, the $42 \%$ decrease in the delta value indicates that LPS treatment significantly decreases CSF bulk flow. Figure $3 \mathrm{~b}$ shows that serum levels of ${ }^{14} \mathrm{C}$-inulin also significantly decrease with LPS, further demonstrating that CSF bulk flow is impaired in this model.

\section{Brain microvascular expression of LRP-1 and pgp, and oxidative modification of LRP-1}

To determine effects of LPS on efflux transporter expression, we first measured levels of LRP-1 and Pgp in brain microvessels isolated from mice treated with LPS or saline. Figure 4 shows that neither LRP-1 (Figure 4ac) nor Pgp (Figure $4 \mathrm{~d}, \mathrm{e}$ ) levels are altered significantly with LPS in isolated brain microvessels. Because it was found that oxidative modification of LRP-1 significantly increases in the AD hippocampus, and inflammation is associated with increased oxidative stress in the brain, we determined whether similar patterns in oxidative modification were present in isolated brain microvessels in our model. Figure 5 shows that no significant alterations in oxidative modification of LRP-1 occur with LPS. Interestingly, oxidative modifications to LRP-1 were not detectable in capillary-depleted brain homogenate from either group tested (data not shown).

\section{LPS effects on LRP-1 expression in vitro}

Although no changes were found for LRP-1 expression in isolated brain microvessels following LPS treatment in vivo, we have recently found that cultured brain microvascular pericytes upregulate LRP-1 when treated with LPS in vitro [48]. Mechanical preparations of isolated brain microvessels include pericytes, due to their juxtaposition to endothelial cells [49]. This raises the possibility that pericyte upregulation of LRP-1 masks downregulation of LRP-1 at the endothelial cell. To test this, we treated primary cultures of HBECs, the rat brain endothelial cell line RBE4, and primary cultures of mouse brain endothelial cells (MBECs) with LPS and measured LRP-1 protein expression or localization following treatment. Figure 6 shows that LRP-1 is significantly downregulated following LPS treatment in both HBECs (Figure 6a,b) and the RBE4 cell line (Figure 6c). We were unable to detect Pgp in primary pericytes using the same antibody (data not shown). In
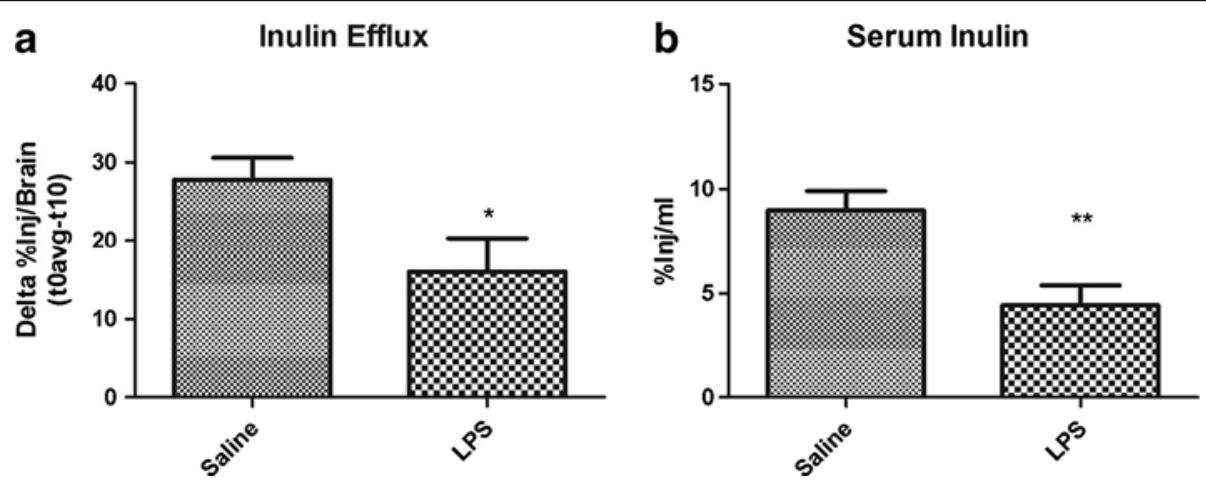

Figure 3 Brain efflux of ICV-injected ${ }^{14} \mathrm{C}$ inulin (a) and corresponding appearance in serum (b) after treatment with LPS. Lower values indicate slower efflux. Data analyzed by two-tailed t-test, $n=10$ per group, ${ }^{*} P<0.05$, ${ }^{* *} P<0.01$. 


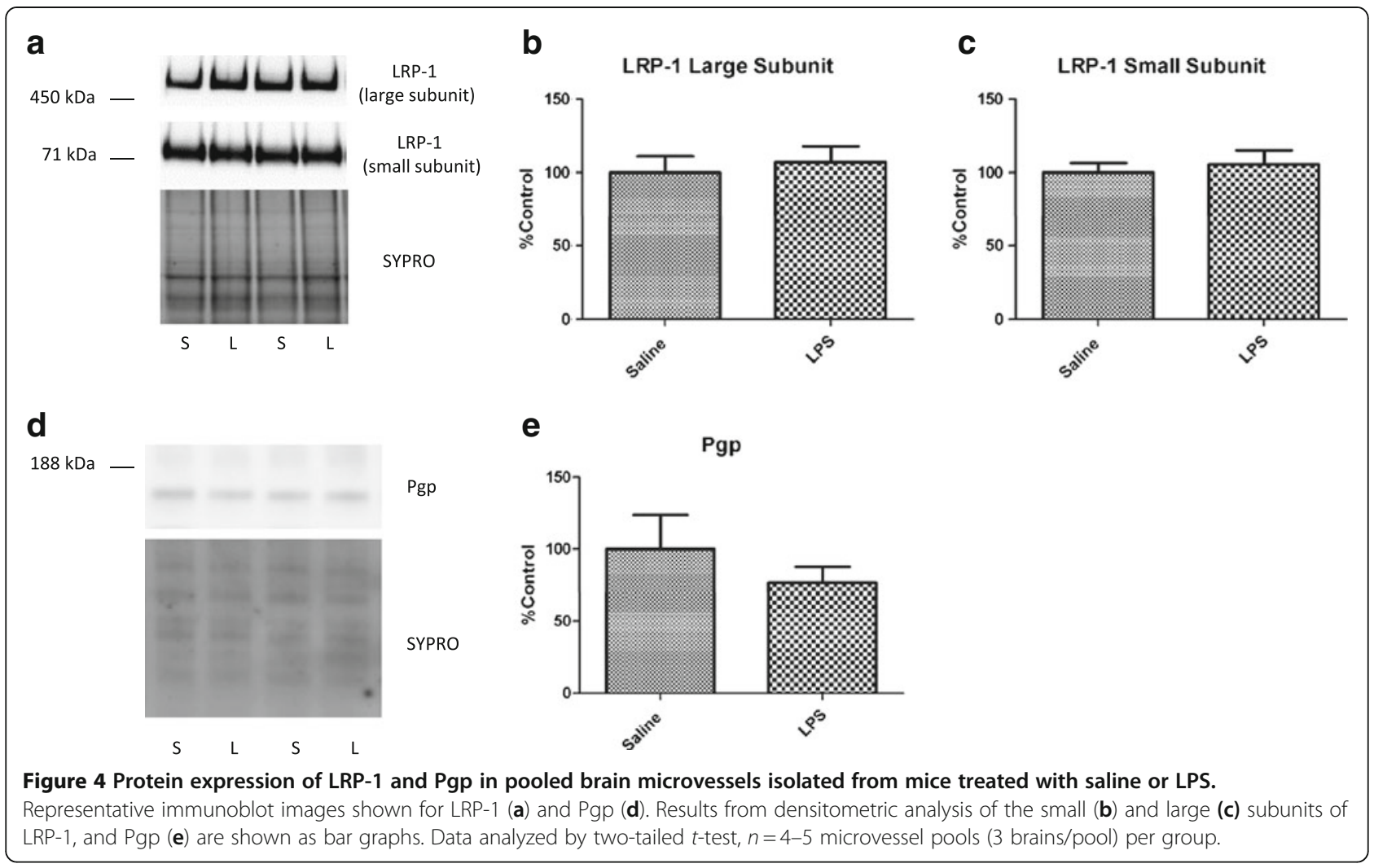

addition to downregulation, Figure 7 shows that LRP-1 mislocalization occurs following LPS treatment in MBECs. This change is associated with mislocalization of the tight junction protein ZO-1.

\section{Discussion and conclusions}

In this study we have shown that peripheral administration of LPS inhibits CSF bulk flow, central and peripheral clearance of $A \beta$, and increases vascular sequestration of $A \beta$. All four of these positive results demonstrate that systemic inflammation alters the distribution of $A B$ in ways that would favor its accumulation in brain. Other groups have shown LRP-1-dependent efflux of human forms of $\mathrm{A} \beta$ across the $\mathrm{BBB}[4,50]$, however, we have observed that murine $A \beta_{1-42}$ also undergoes LRP-1-dependent BBB transport and is cleared at a faster rate across the murine $\mathrm{BBB}$ than human $A \beta_{1-42}[7,51]$. Although we did not observe direct changes to LRP-1 or Pgp in vivo, our findings of increased vascular partitioning of $A \beta$ and decreased

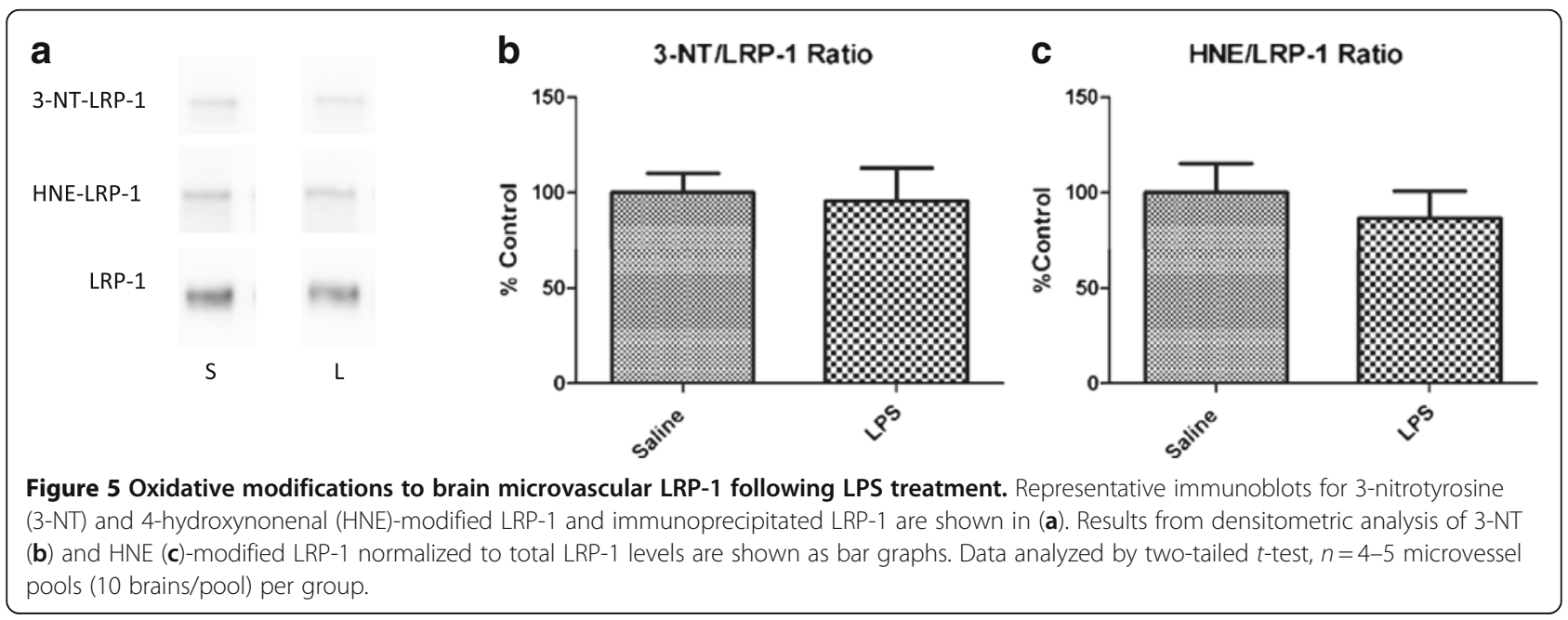



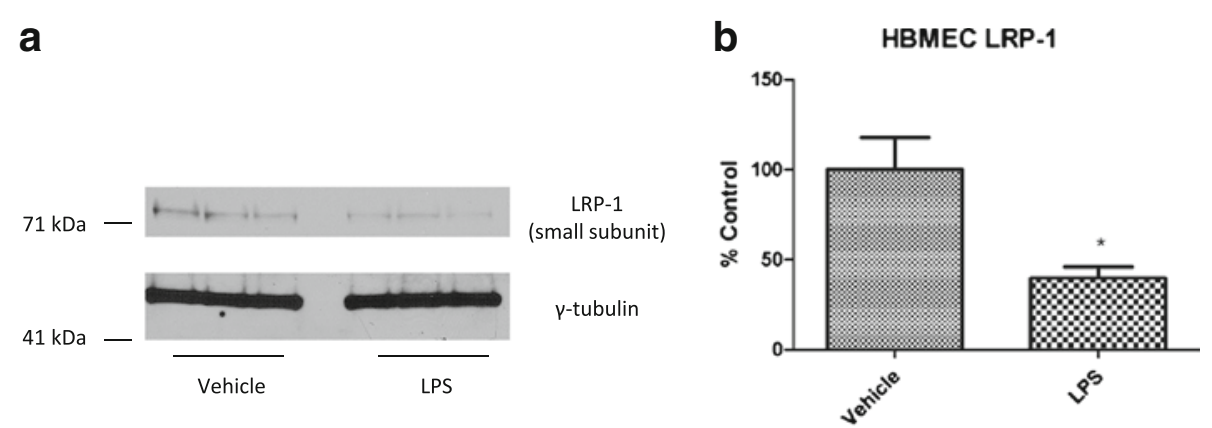

C RBE4 LRP-1

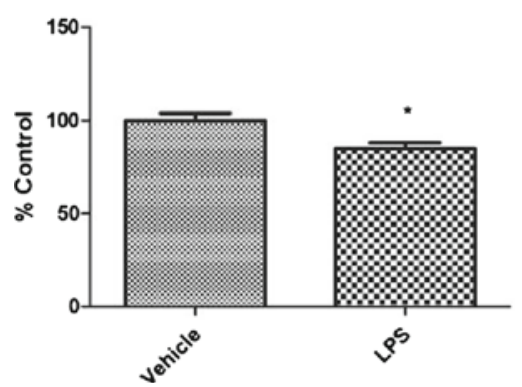

Figure 6 Decreased protein expression of LRP-1 in cultured HBECs and RBE4 cells following LPS treatment. Immunoblots of LRP-1 and $\gamma$-tubulin from HBECs are shown in (a), and densitometric analysis of LRP-1 small subunit expression shown in (b). Data from dot blot analysis of LRP-1 in RBE4 cells is shown in (c). Data analyzed by two-tailed $t$-test, $n=3$ per group (HBEC) or 6 per group (RBE4), ${ }^{*} P<0.05$.

LRP-1 expression in cultured brain endothelial cells provides important clues of how BBB transport dysfunction could occur, as modeled in Figure 8.

The finding that inulin efflux from brain is decreased following LPS administration demonstrates that CSF/ interstitial fluid (ISF) bulk flow decreases in our model. CSF/ISF turnover is important for clearing catabolites

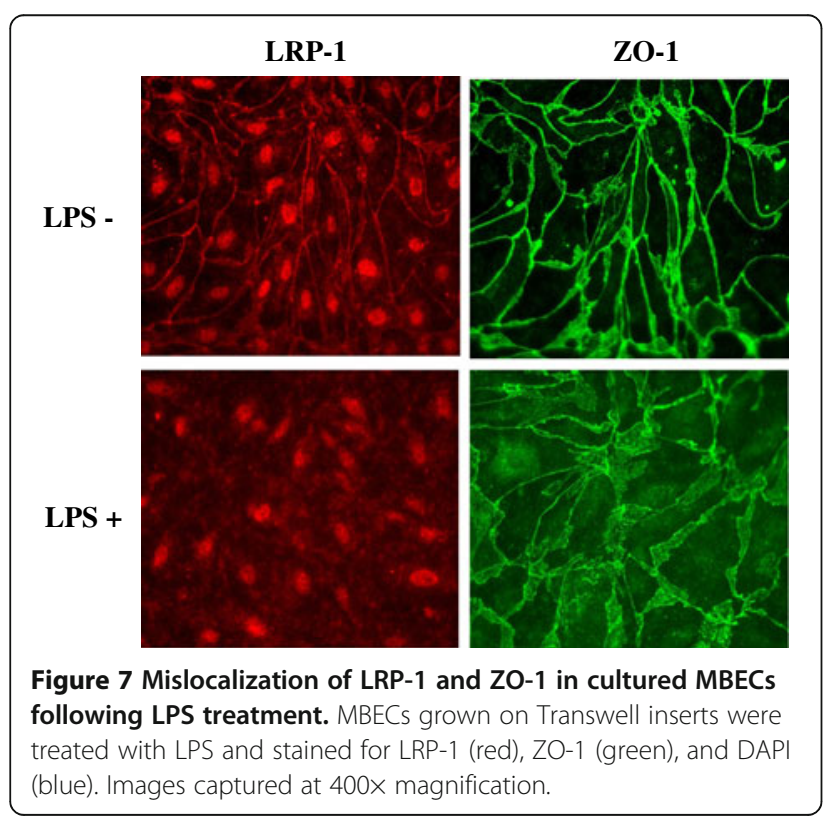

from the brain, and maintaining an optimal environment for neuronal function [14,52]. It has been shown that substantial catabolite buildup occurs after a $50 \%$ decrease in CNS fluid turnover rate, and this can lead to neuronal toxicity [14]. This rate of decrease is observed in $\mathrm{AD}$, and therefore may contribute to toxic catabolite buildup in the $A D$ brain [52]. In healthy animals and humans, the magnitude of $A \beta$ efflux by the saturable BBB systems is much greater than clearance by bulk flow [4], but transporter deficiency could result in a shift where bulk flow becomes the predominant clearance route. In our LPS model we observed a $42 \%$ decrease in inulin efflux compared with control. This shows that similar to AD, bulk flow is also impaired during systemic inflammation. Future studies are necessary to determine to what extent this deficit contributes to cognitive dysfunction.

In addition to its contribution to bulk flow, the bloodCSF barrier is likely to play important roles in $A \beta$ removal from CSF. Epithelial cells of the choroid plexus have saturable transport systems for $A \beta$ [53], and LRP-1 at the choroid plexus participates in the clearance of $A \beta$ from the CSF [54]. This may have important implications for AD because LRP-1 expression increases in the rat choroid plexus with age [55]. ICV-injected $A \beta$ would be subject to transport by LRP-1 at the BBB and bloodCSF barrier, and the relative contribution of each route to total clearance is presently unclear. Whether LPS 


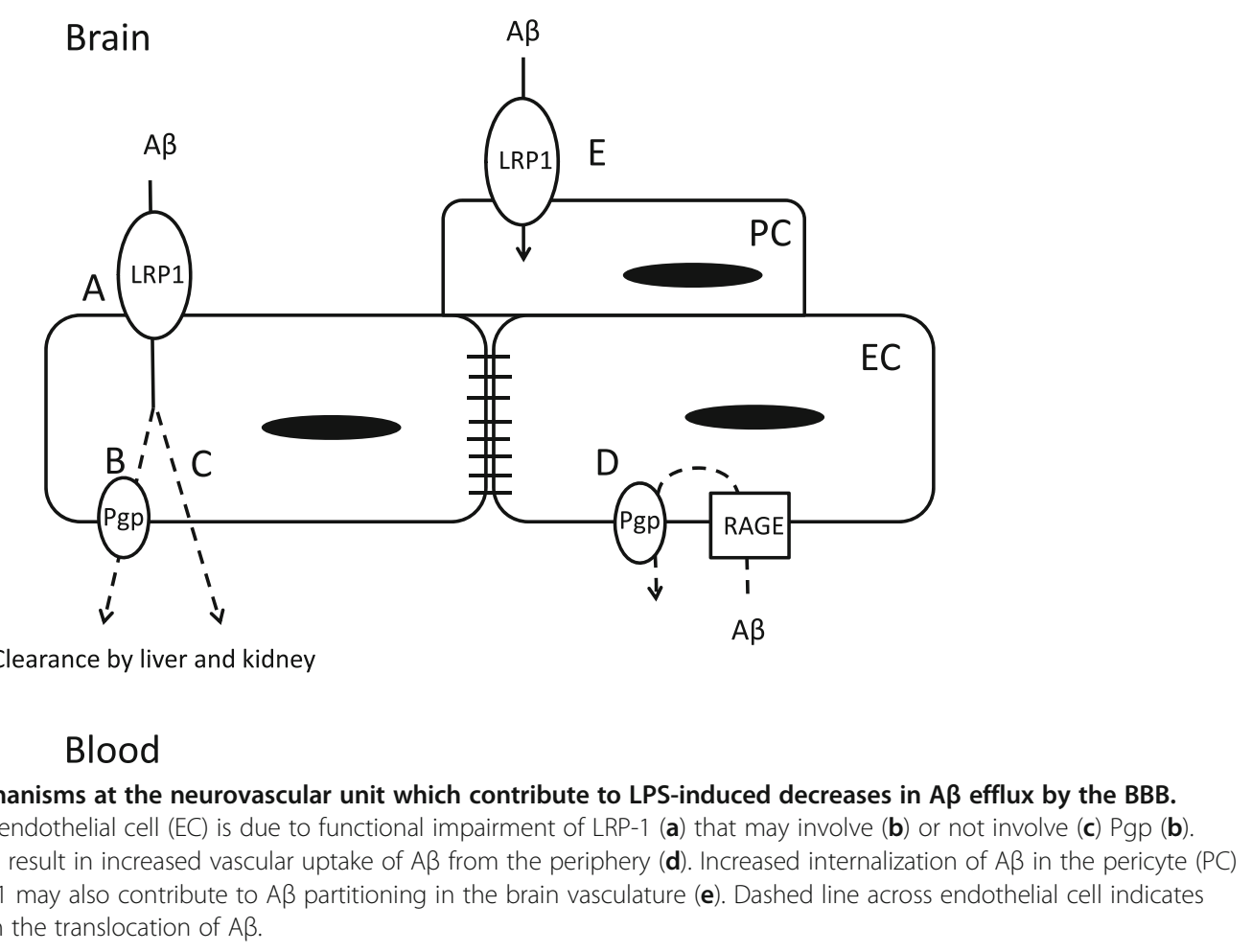

alters LRP-1 function at the choroid plexus is also unknown, but this could reflect an additional mechanism involved in the observed $A \beta$ clearance deficit.

Peripheral clearance of $A \beta$ from the circulation is primarily dependent on uptake by the liver and kidneys [16]. In this study we measured clearance of $A \beta$ from blood along with liver and kidney uptake to confirm that brain-derived $A \beta$ contributes substantially to measurements of $A \beta$ in blood. The finding that $A \beta$ levels were decreased in blood following LPS even though a decrease in peripheral clearance was observed shows that serum levels of exogenous $A \beta$ underestimate the magnitude of LPS inhibition on A $\beta$ efflux from brain. Despite this, we found that LPS causes a significant reduction of ICV-injected $A \beta$ in serum, which supports previous results that LPS impairs $A \beta$ efflux from brain. The observation of decreased $A \beta$ clearance from blood by both liver and kidney is also of interest. Because LRP-1 mediates peripheral clearance of $A \beta$ in liver [17] our findings suggest LRP-1 impairment may be occurring with LPS at peripheral sites. Whether $\mathrm{A} \beta$ clearance by kidney is also mediated by LRP-1 is unknown, but reflects a likely route as LRP-1 is expressed in kidney. LRP-1 is known to be cleaved in response to inflammatory stimuli [33], which may reflect a mechanism for peripheral LRP-1 dysfunction in our LPS model. Reduced peripheral clearance of $A \beta$ may be contributing to $A \beta$ accumulation in brain through increased BBB influx via RAGE [18,32], as well as by decreasing $A \beta$ efflux [19]. The latter mechanism may be explained either by decreases in the $\mathrm{A} \beta$ concentration gradient between brain and blood, or endothelial dysfunction through RAGE activation. Because studies indicate that processes regulating circulating $\mathrm{A} \beta$ play important roles in $\mathrm{AD}$ pathogenesis $[56,57]$, these results highlight a novel mechanism by which systemic inflammation could contribute to AD.

Our findings of decreased brain efflux and increased neurovascular $A \beta$ sequestration with LPS could be explained by the interaction of several pathways as illustrated by the working model in Figure 8 . The first consideration of Figure 8 is the subcellular location of the efflux transporters LRP-1 and Pgp. The model presented here, in line with a recently reported model [11], starts with extracellular $A \beta$ first coming into contact with LRP-1 on the abluminal side of the brain endothelial cell (Figure 8a). This is followed by transport of $A \beta$ into the vascular lumen by Pgp (Figure 8b), or by a Pgpindependent pathway (Figure 8c). Entry of circulating $A \beta$ into the brain is mediated by RAGE, but can also be restricted by Pgp [39] (Figure 8d). Our result showing that vascular $A \beta$ and $a 2 M$ partitioning increases with LPS is consistent with a functional deficit in LRP-1. This would not, however, be due to mechanisms that decrease binding interactions between A $\beta$ and LRP-1 such as ligand competition $[58,59]$ because this would be expected to decrease vascular partitioning. Along these lines, our observations of decreased expression of LRP-1 at the endothelial cell are inconsistent with increased vascular 
partitioning unless other cells of the neurovascular unit are considered. LRP-1 expressed in other cells tightly associated with the neurovasculature such as pericytes and vascular smooth muscle cells could contribute to vascular partitioning $[60,61]$ because these cells remain associated with the vascular pellet. Therefore, increased vascular partitioning may also reflect an increase in uptake of $A \beta$ by pericytes or vascular smooth muscle cells (Figure 8e). Interpretation of the results for vascular sequestration is discussed below in context of our findings for transporter expression and what is known from the literature about LRP-1 and Pgp regulation.

Our in vivo findings for $\mathrm{BBB}$ transporter expression showed no significant changes in LRP-1 or Pgp expression following LPS treatment, nor did we find increases in oxidative modifications to LRP-1. Interestingly, we did find that oxidative modifications to LRP-1 which were detectable in brain endothelial cells of saline-treated animals were not detected in capillary-depleted parenchymal fractions from the same isolation, despite strong immunostaining for immunoprecipitated LRP-1 (data not shown). Although LRP-1 is generally considered to be a receptor that recycles from membrane to lysosomal compartments, it has been shown that phosphorylation can regulate this process [62]. Oxidative modification to LRP-1 could alter such processes, impairing unique physiological functions, such as transcytosis at the BBB. Recently, it has been shown that LRP-1 transcytosis occurs in an in vitro BBB model [63]. Future studies are necessary to determine whether post-translational modifications are needed to confer unique functions to LRP-1 at the BBB.

Despite our inability to show LPS-induced changes in BBB LRP-1 in vivo, we did find that LRP-1 expression was significantly decreased by treating cultured HMECs or RBE4 cells with LPS in vitro. This is opposite to the effect we recently reported for primary cultured pericytes, which upregulate LRP-1 in response to LPS [48]. Therefore, the possibility is raised that upregulation of LRP-1 at the pericyte masks downregulation of LRP-1 at the endothelial cell, which would explain our findings of decreased BBB efflux in the absence of changes in protein expression in vivo. Furthermore, increased expression of LRP-1 at the pericyte could also explain our finding that the distribution of ICV-injected $A \beta$ shifts from the parenchyma to the vascular compartment. Mislocalization of LRP-1 was also found to occur with LPS in primary brain endothelial cells, further supporting that LPS induces LRP-1 dysfunction at the brain endothelial cell. Because LRP-1 participates in A $\beta$ internalization and transport in vitro $[50,60,63]$, future studies are necessary to determine how these in vitro changes in LRP-1 alter the cellular uptake and transport of $A \beta$.
It is possible that in addition to LRP-1, Pgp dysfunction may also contribute to increased vascular partitioning and decreased BBB efflux of $A \beta$. Although we found no changes in Pgp expression in vivo following LPS, this does not contradict other reports in the literature where Pgp is functionally inhibited despite unchanged or upregulated protein expression $[36,37,64,65]$. Furthermore, we and others have found that the LPS regimen used in this study impairs Pgp function at the BBB $[38,64]$. Therefore, Pgp dysfunction could also be mediating defects in $A \beta$ transport. Our inability to show a significant decrease in Pgp expression also signifies an important difference between our model and $A D$ because Pgp is downregulated in the brain microvasculature in $\mathrm{AD}$ [12].

Together, these results show that $\mathrm{BBB} A \beta$ transport is functionally impaired following an inflammatory response. Although our in vitro data suggest that LPS downregulates LRP-1 at the brain endothelial cell in vivo, the lack of any significant decrease in Pgp expression highlights an important distinction from $\mathrm{AD}$, where both LRP-1 and Pgp are downregulated in the brain microvasculature. An explanation for this distinction may be related to our use of young adult mice in this study. Because $A \beta$ is produced under normal physiological conditions, and our data utilizes an acute model of systemic inflammation [66], it may be that the mechanistic differences observed for $A \beta$ efflux deficiency in inflammation and $\mathrm{AD}$ represent components of a physiological process. $A \beta$ has been implicated as a stress-response molecule [67], and at physiological levels has neuroprotective properties $[30,68]$. Hence, it is tempting to speculate that downregulation of $\mathrm{BBB}$ efflux transporters in $\mathrm{AD}$ may represent a pathological consequence of prolonged vascular sequestration of $A \beta$ as a result of sustained systemic inflammation. This possibility is supported by another group who showed in a transgenic model of AD that Pgp dysfunction at the BBB precedes symptoms of cognitive impairment, and that microvascular upregulation of LRP-1 also occurs at this time point [11]. Furthermore, cerebrovascular accumulation of $A \beta$ is cytotoxic [61]. Because low-grade systemic inflammation is associated with many other diseases which have been considered comorbidities in AD [69], similar comparative studies would be useful in determining unifying pathological events at the neurovascular unit or related to brain fluid dynamics which would contribute to impaired $A \beta$ clearance from the brain. Aging would likely sensitize an organism to inflammation so that the threshold required for $A \beta$ efflux impairment is lowered [70]. In conclusion, we have shown that inflammatory events at the neurovascular unit affect key players that regulate the brain and blood levels of $A \beta$, providing mechanistic pathways by which inflammation 
could promote or even induce important characteristics of $\mathrm{AD}$.

\section{Competing interests}

The authors declare that they have no competing interests.

\section{Acknowledgements}

We would like to thank Dr Guojun Bu for providing technical advice on the immunodetection of LRP-1. This project was funded by NIGMS 5T32GM008306-20 and NIH AG-029839.

\section{Author details}

'Department of Pharmacology and Physiology, Saint Louis University, 1402 South Grand Blvd, St. Louis, MO 63104, USA. ${ }^{2}$ GRECC, Veterans Affairs Puget Sound Health Care System, 1600 S. Columbian Way, Seattle, WA 98108, USA. ${ }^{3}$ Division of Gerontology and Geriatric Medicine, Department of Internal Medicine, University of Washington School of Medicine, Bldg. 1, Rm. 810A, 1660 Columbian Way, Seattle, WA 98108, USA. ${ }^{4}$ Department of Chemistry, Center of Membrane Sciences and Sander-Brown Center on Aging, University of Kentucky, 249 Chemistry-Physics Building, Lexington, KY 40506, USA.

\section{Authors' contributions}

ME participated in the conception and design of the study, carried out or oversaw all experimental studies and drafted the manuscript. PEH carried out the measurements of systemic clearance of $A \beta$, and assisted in drafting the manuscript. YM carried out the primary endothelial cell and RBE4 cultures and treatments, as well as the immunofluorescence measurements of LRP-1 and ZO-1, and assisted in drafting the manuscript. JBO assisted with tissue processing, provided technical assistance for the measurement of LRP-1 oxidation, and assisted in drafting the manuscript. DAB assisted with the conception and design of the study. WAB conceived and oversaw the design and coordination of the study, and assisted in drafting the manuscript. All authors read and approved the final manuscript.

Received: 27 February 2012 Accepted: 29 June 2012

Published: 29 June 2012

\section{References}

1. Thies W, Bleiler L: 2011 Alzheimer's disease facts and figures. Alzheimers Dement 2011, 7:208-244.

2. Hardy J, Selkoe DJ: The amyloid hypothesis of Alzheimer's disease: progress and problems on the road to therapeutics. Science 2002, 297:353-356.

3. Zlokovic BV, Deane R, Sagare AP, Bell RD, Winkler EA: Low-density lipoprotein receptor-related protein-1: a serial clearance homeostatic mechanism controlling Alzheimer's amyloid beta-peptide elimination from the brain. J Neurochem 2010, 115:1077-1089.

4. Shibata M, Yamada S, Kumar SR, Calero M, Bading J, Frangione B, Holtzman DM, Miller CA, Strickland DK, Ghiso J, Zlokovic BV: Clearance of Alzheimer's amyloid-ss(1-40) peptide from brain by LDL receptor-related protein-1 at the blood-brain barrier. J Clin Invest 2000, 106:1489-1499.

5. Deane R, Wu Z, Sagare A, Davis J, Du Yan S, Hamm K, Xu F, Parisi M, LaRue B, Hu HW, Spijkers P, Guo H, Song X, Lenting PJ, Van Nostrand WE, Zlokovic BV: LRP/amyloid beta-peptide interaction mediates differential brain efflux of Abeta isoforms. Neuron 2004, 43:333-344.

6. Kandimalla KK, Curran GL, Holasek SS, Gilles EJ, Wengenack TM, Poduslo JF: Pharmacokinetic analysis of the blood-brain barrier transport of 1251 -amyloid beta protein 40 in wild-type and Alzheimer's disease transgenic mice (APP, PS1) and its implications for amyloid plaque formation. J Pharmacol Exp Ther 2005, 313:1370-1378.

7. Jaeger LB, Dohgu S, Hwang MC, Farr SA, Murphy MP, Fleegal-DeMotta MA, Lynch JL, Robinson SM, Niehoff ML, Johnson SN, Kumar VB, Banks WA: Testing the neurovascular hypothesis of Alzheimer's disease: LRP-1 antisense reduces blood-brain barrier clearance, increases brain levels of amyloid-beta protein, and impairs cognition. J Alzheimers Dis 2009 , 17:553-570.

8. Donahue JE, Flaherty $S L$, Johanson $C E$, Duncan JA 3rd, Silverberg GD, Miller MC, Tavares R, Yang W, Wu Q, Sabo E, Hovanesian V, Stopa EG: RAGE, LRP-1, and amyloid-beta protein in Alzheimer's disease. Acta Neuropathol 2006, 112:405-415.
9. Owen JB, Sultana R, Aluise CD, Erickson MA, Price TO, Bu G, Banks WA, Butterfield DA: Oxidative modification to LDL receptor-related protein 1 in hippocampus from subjects with Alzheimer disease: implications for Abeta accumulation in AD brain. Free Radic Biol Med 2010, 49:1798-1803.

10. Cirrito JR, Deane R, Fagan AM, Spinner ML, Parsadanian M, Finn MB, Jiang H, Prior IL, Sagare A, Bales KR, Paul SM, Zlokovic BV, Piwnica-Worms D, Holtzman DM: P-glycoprotein deficiency at the blood-brain barrier increases amyloid-beta deposition in an Alzheimer disease mouse model. J Clin Invest 2005, 115:3285-3290.

11. Hartz AM, Miller DS, Bauer B: Restoring blood-brain barrier P-glycoprotein reduces brain amyloid-beta in a mouse model of Alzheimer's disease. Mol Pharmacol 2010, 77:715-723.

12. Wijesuriya HC, Bullock JY, Faull RL, Hladky SB, Barrand MA: ABC efflux transporters in brain vasculature of Alzheimer's subjects. Brain Res 2010, 1358:228-238

13. Boulton M, Flessner M, Armstrong D, Mohamed R, Hay J, Johnston M: Contribution of extracranial lymphatics and arachnoid villi to the clearance of a CSF tracer in the rat. Am J Physiol 1999, 276:R818-R823.

14. Johanson CE, Duncan JA 3rd, Klinge PM, Brinker T, Stopa EG, Silverberg GD: Multiplicity of cerebrospinal fluid functions: new challenges in health and disease. Cerebrospinal Fluid Res 2008, 5:10.

15. Banks WA, Kumar VB, Farr SA, Nakaoke R, Robinson SM, Morley JE: Impairments in brain-to-blood transport of amyloid-beta and reabsorption of cerebrospinal fluid in an animal model of Alzheimer's disease are reversed by antisense directed against amyloid-beta protein precursor. J Alzheimers Dis 2011, 23:599-605.

16. Ghiso J, Shayo M, Calero M, Ng D, Tomidokoro Y, Gandy S, Rostagno A, Frangione B: Systemic catabolism of Alzheimer's Abeta40 and Abeta42. J Biol Chem 2004, 279:45897-45908.

17. Tamaki C, Ohtsuki S, Iwatsubo T, Hashimoto T, Yamada K, Yabuki C, Terasaki T: Major involvement of low-density lipoprotein receptor-related protein 1 in the clearance of plasma free amyloid beta-peptide by the liver. Pharm Res 2006, 23:1407-1416.

18. Deane R, Du Yan S, Submamaryan RK, LaRue B, Jovanovic S, Hogg E, Welch D, Manness L, Lin C, Yu J, Zhu H, Ghiso J, Frangione B, Stern A, Schmidt AM, Armstrong DL, Arnold B, Liliensiek B, Nawroth P, Hofman F, Kindy M, Stern D, Zlokovic B: RAGE mediates amyloid-beta peptide transport across the blood-brain barrier and accumulation in brain. Nat Med 2003, 9:907-913.

19. Marques MA, Kulstad JJ, Savard CE, Green PS, Lee SP, Craft S, Watson GS, Cook DG: Peripheral amyloid-beta levels regulate amyloidbeta clearance from the central nervous system. J Alzheimers Dis 2009, 16:325-329.

20. Baiguera S, Fioravanzo L, Grandi C, Di Liddo R, Parnigotto PP, Folin M: Involvement of the receptor for advanced glycation-end products (RAGE) in beta-amyloid-induced toxic effects in rat cerebromicrovascular endothelial cells cultured in vitro. Int J Mol Med 2009, 24:9-15.

21. Akiyama H, Barger S, Barnum S, Bradt B, Bauer J, Cole GM, Cooper NR, Eikelenboom P, Emmerling M, Fiebich BL, Finch CE, Frautschy S, Griffin WS, Hampel H, Hull M, Landreth G, Lue L, Mrak R, Mackenzie IR, McGeer PL, O'Banion MK, Pachter J, Pasinetti G, Plata-Salaman C, Rogers J, Rydel R, Shen Y, Streit W, Strohmeyer R, Tooyoma I, Van Muiswinkel FL, Veerhuis R, Walker D, Webster S, Wegrzyniak B, Wenk G, Wyss-Coray T: Inflammation and Alzheimer's disease. Neurobiol Aging 2000, 21:383-421.

22. Reed-Geaghan EG, Savage JC, Hise AG, Landreth GE: CD14 and toll-like receptors 2 and 4 are required for fibrillar A\{beta\}-stimulated microglial activation. J Neurosci 2009, 29:11982-11992.

23. Liu S, Liu Y, Hao W, Wolf L, Kiliaan AJ, Penke B, Rube CE, Walter J, Heneka MT, Hartmann T, Menger MD, Fassbender K: TLR2 is a primary receptor for Alzheimer's amyloid beta peptide to trigger neuroinflammatory activation. J Immunol 2012, 188:1098-1107.

24. Butterfield DA, Reed T, Newman SF, Sultana R: Roles of amyloid beta-peptide-associated oxidative stress and brain protein modifications in the pathogenesis of Alzheimer's disease and mild cognitive impairment. Free Radic Biol Med 2007, 43:658-677.

25. Bianca VD, Dusi S, Bianchini E, Dal Pra I, Rossi F: beta-amyloid activates the O-2 forming NADPH oxidase in microglia, monocytes, and neutrophils. A possible inflammatory mechanism of neuronal damage in Alzheimer's disease. J Biol Chem 1999, 274:15493-15499.

26. Donnelly RJ, Friedhoff AJ, Beer B, Blume AJ, Vitek MP: Interleukin-1 stimulates the beta-amyloid precursor protein promoter. Cell $\mathrm{MO}$ Neurobiol 1990, 10:485-495. 
27. Sheng JG, Bora SH, Xu G, Borchelt DR, Price DL, Koliatsos VE: Lipopolysaccharide-induced-neuroinflammation increases intracellula accumulation of amyloid precursor protein and amyloid beta peptide in APPswe transgenic mice. Neurobiol Dis 2003, 14:133-145.

28. Lee JW, Lee YK, Yuk DY, Choi DY, Ban SB, Oh KW, Hong JT: Neuroinflammation induced by lipopolysaccharide causes cognitive impairment through enhancement of beta-amyloid generation. J Neuroinflammation 2008, 5:37.

29. Oda A, Tamaoka A, Araki W: Oxidative stress up-regulates presenilin 1 in lipid rafts in neuronal cells. J Neurosci Res 2010, 88:1137-1145.

30. Kontush A: Amyloid-beta: an antioxidant that becomes a pro-oxidant and critically contributes to Alzheimer's disease. Free Radic Biol Med 2001, 31:1120-1131.

31. Neniskyte U, Neher JJ, Brown GC: Neuronal death induced by nanomolar amyloid beta is mediated by primary phagocytosis of neurons by microglia. J Biol Chem 2011, 286:39904-39913.

32. Jaeger LB, Dohgu S, Sultana R, Lynch JL, Owen JB, Erickson MA, Shah GN, Price TO, Fleegal-Demotta MA, Butterfield DA, Banks WA: Lipopolysaccharide alters the blood-brain barrier transport of amyloid beta protein: a mechanism for inflammation in the progression of Alzheimer's disease. Brain Behav Immun 2009, 23:507-517.

33. Zurhove K, Nakajima C, Herz J, Bock HH, May P: Gamma-secretase limits the inflammatory response through the processing of LRP1. Sci Signal 2008, 1:ra15

34. Polavarapu R, An J, Zhang C, Yepes M: Regulated intramembrane proteolysis of the low-density lipoprotein receptor-related protein mediates ischemic cell death. Am J Pathol 2008, 172:1355-1362.

35. Kheir-Eldin AA, Motawi TK, Gad MZ, Abd-ElGawad HM: Protective effect of vitamin $\mathrm{E}$, beta-carotene and $\mathrm{N}$-acetylcysteine from the brain oxidative stress induced in rats by lipopolysaccharide. Int J Biochem Cell Biol 2001, 33:475-482

36. Pan $W, Y u$ C, Hsuchou $H$, Kastin AJ: The role of cerebral vascular NFkappaB in LPS-induced inflammation: differential regulation of efflux transporter and transporting cytokine receptors. Cell Physiol Biochem 2010, 25:623-630.

37. Hartz AM, Bauer B, Fricker G, Miller DS: Rapid modulation of Pglycoprotein-mediated transport at the blood-brain barrier by tumor necrosis factor-alpha and lipopolysaccharide. Mol Pharmacol 2006 69:462-470.

38. Jin L, Li J, Nation RL, Nicolazzo JA: Impact of p-glycoprotein inhibition and lipopolysaccharide administration on blood-brain barrier transport of colistin in mice. Antimicrob Agents Chemother 2011, 55:502-507.

39. Candela P, Gosselet F, Saint-Pol J, Sevin E, Boucau MC, Boulanger E, Cecchelli R, Fenart L: Apical-to-basolateral transport of amyloid-beta peptides through blood-brain barrier cells is mediated by the receptor for advanced glycation end-products and is restricted by P-glycoprotein. J Alzheimers Dis 2010, 22:849-859.

40. Imber MJ, Pizzo SV: Clearance and binding of two electrophoretic 'fast' forms of human alpha 2-macroglobulin. J Biol Chem 1981, 256:8134-8139.

41. Greenwood FC, Hunter WM, Glover JS: The preparation of I-131-labelled human growth hormone of high specific radioactivity. Biochem J 1963, 89:114-123.

42. Triguero D, Buciak J, Pardridge WM: Capillary depletion method for quantification of blood-brain barrier transport of circulating peptides and plasma proteins. J Neurochem 1990, 54:1882-1888.

43. Patlak CS, Blasberg RG, Fenstermacher JD: Graphical evaluation of bloodto-brain transfer constants from multiple-time uptake data. J Cereb Blood Flow Metab 1983, 3:1-7.

44. Gerhart DZ, Broderius MA, Drewes LR: Cultured human and canine endothelial cells from brain microvessels. Brain Res Bull 1988, 21:785-793.

45. Coisne C, Dehouck L, Faveeuw C, Delplace Y, Miller F, Landry C, Morissette C, Fenart L, Cecchelli R, Tremblay P, Dehouck B: Mouse syngenic in vitro blood-brain barrier model: a new tool to examine inflammatory events in cerebral endothelium. Lab Invest 2005, 85:734-746.

46. Perriere N, Demeuse P, Garcia E, Regina A, Debray M, Andreux JP, Couvreur P, Scherrmann JM, Temsamani J, Couraud PO, Deli MA, Roux F: Puromycin-based purification of rat brain capillary endothelial cell cultures. Effect on the expression of blood-brain barrier-specific properties. J Neurochem 2005, 93:279-289.

47. Erickson MA, Niehoff ML, Farr SA, Morley JE, Dillman LA, Lynch KM, Banks WA: Peripheral administration of antisense oligonucleotides targeting the amyloid-beta protein precursor reverses AbetaPP and LRP- 1 overexpression in the aged SAMP8 mouse brain. J Alzheimers Dis 2012 28:951-960

48. Kovac A, Erickson MA, Banks WA: Brain microvascular pericytes are immunoactive in culture: cytokine, chemokine, nitric oxide, and LRP-1 expression in response to lipopolysaccharide. J Neuroinflammation 2011, 8:139

49. Lai $\mathrm{CH}$, Kuo $\mathrm{KH}$ : The critical component to establish in vitro BBB model: pericyte. Brain Res Brain Res Rev 2005, 50:258-265.

50. Yamada K, Hashimoto T, Yabuki C, Nagae Y, Tachikawa M, Strickland DK, Liu Q, Bu G, Basak JM, Holtzman DM, Ohtsuki S, Terasaki T, Iwatsubo T: The low density lipoprotein receptor-related protein 1 mediates uptake of amyloid beta peptides in an in vitro model of the blood-brain barrier cells. J Biol Chem 2008, 283:34554-34562.

51. Banks WA, Robinson SM, Verma S, Morley JE: Efflux of human and mouse amyloid beta proteins 1-40 and 1-42 from brain: impairment in a mouse model of Alzheimer's disease. Neuroscience 2003, 121:487-492.

52. Rubenstein E: Relationship of senescence of cerebrospinal fluid circulatory system to dementias of the aged. Lancet 1998, 351:283-285.

53. Crossgrove JS, Li GJ, Zheng W: The choroid plexus removes beta-amyloid from brain cerebrospinal fluid. Exp Biol Med (Maywood) 2005, 230:771-776.

54. Fujiyoshi M, Tachikawa M, Ohtsuki S, Ito S, Uchida Y, Akanuma S, Kamiie J, Hashimoto T, Hosoya K, Iwatsubo T, Terasaki T: Amyloid-beta peptide (1-40) elimination from cerebrospinal fluid involves low-density lipoprotein receptor-related protein 1 at the blood-cerebrospinal fluid barrier. J Neurochem 2011, 118:407-415.

55. Pascale CL, Miller MC, Chiu C, Boylan M, Caralopoulos IN, Gonzalez L, Johanson CE, Silverberg GD: Amyloid-beta transporter expression at the blood-CSF barrier is age-dependent. Fluids Barriers CNS 2011, 8:21.

56. Sagare AP, Winkler EA, Bell RD, Deane R, Zlokovic BV: From the liver to the blood-brain barrier: an interconnected system regulating brain amyloidbeta levels. J Neurosci Res 2011, 89:967-968.

57. Sutcliffe JG, Hedlund PB, Thomas EA, Bloom FE, Hilbush BS: Peripheral reduction of beta-amyloid is sufficient to reduce brain beta-amyloid: implications for Alzheimer's disease. J Neurosci Res 2011, 89:808-814.

58. Ito S, Ohtsuki S, Kamiie J, Nezu Y, Terasaki T: Cerebral clearance of human amyloid-beta peptide (1-40) across the blood-brain barrier is reduced by self-aggregation and formation of low-density lipoprotein receptorrelated protein-1 ligand complexes. J Neurochem 2007, 103:2482-2490.

59. Bell RD, Sagare AP, Friedman AE, Bedi GS, Holtzman DM, Deane R, Zlokovic BV: Transport pathways for clearance of human Alzheimer's amyloid beta-peptide and apolipoproteins $E$ and $J$ in the mouse central nervous system. J Cereb Blood Flow Metab 2007, 27:909-918.

60. Bell RD, Deane R, Chow N, Long X, Sagare A, Singh I, Streb JW, Guo H, Rubio A, Van Nostrand W, Miano JM, Zlokovic BV: SRF and myocardin regulate LRP-mediated amyloid-beta clearance in brain vascular cells. Nat Cell Biol 2009, 11:143-153.

61. Wilhelmus MM, Otte-Holler I, van Triel JJ, Veerhuis R, Maat-Schieman ML, Bu G, de Waal RM, Verbeek MM: Lipoprotein receptor-related protein-1 mediates amyloid-beta-mediated cell death of cerebrovascular cells. Am J Pathol 2007, 171:1989-1999.

62. van der Geer P: Phosphorylation of LRP1: regulation of transport and signal transduction. Trends Cardiovasc Med 2002, 12:160-165.

63. Pflanzner T, Janko MC, Andre-Dohmen B, Reuss S, Weggen S, Roebroek AJ, Kuhlmann CR, Pietrzik CU: LRP1 mediates bidirectional transcytosis of amyloid-beta across the blood-brain barrier. Neurobiol Aging 2011 32(2323):e2321-2311.

64. Salkeni MA, Lynch JL, Otamis-Price T, Banks WA: Lipopolysaccharide impairs blood-brain barrier P-glycoprotein function in mice through prostaglandin- and nitric oxide-independent pathways. J Neuroimmune Pharmacol 2009, 4:276-282

65. Hawkins BT, Rigor RR, Miller DS: Rapid loss of blood-brain barrier P-glycoprotein activity through transporter internalization demonstrated using a novel in situ proteolysis protection assay. J Cereb Blood Flow Metab 2010, 30:1593-1597.

66. Erickson MA, Banks WA: Cytokine and chemokine responses in serum and brain after single and repeated injections of lipopolysaccharide: multiplex quantification with path analysis. Brain Behav Immun 2011 25:1637-1648

67. Ray B, Gaskins DL, Sajdyk TJ, Spence JP, Fitz SD, Shekhar A, Lahiri DK Restraint stress and repeated corticotrophin-releasing factor receptor 
activation in the amygdala both increase amyloid-beta precursor protein and amyloid-beta peptide but have divergent effects on brain-derived neurotrophic factor and pre-synaptic proteins in the prefrontal cortex of rats. Neuroscience 2011, 184:139-150.

68. Morley JE, Farr SA, Banks WA, Johnson SN, Yamada KA, Xu L: A physiological role for amyloid-beta protein: enhancement of learning and memory. J Alzheimers Dis 2010, 19:441-449.

69. Chung HY, Cesari M, Anton S, Marzetti E, Giovannini S, Seo AY, Carter C, Yu BP, Leeuwenburgh C: Molecular inflammation: underpinnings of aging and age-related diseases. Ageing Res Rev 2009, 8:18-30.

70. Rink L, Cakman I, Kirchner H: Altered cytokine production in the elderly. Mech Ageing Dev 1998, 102:199-209.

doi:10.1186/1742-2094-9-150

Cite this article as: Erickson et al:: Lipopolysaccharide impairs amyloid beta efflux from brain: altered vascular sequestration, cerebrospinal fluid reabsorption, peripheral clearance and transporter function at the blood-brain barrier. Journal of Neuroinflammation 2012 9:150.

\section{Submit your next manuscript to BioMed Central and take full advantage of:}

- Convenient online submission

- Thorough peer review

- No space constraints or color figure charges

- Immediate publication on acceptance

- Inclusion in PubMed, CAS, Scopus and Google Scholar

- Research which is freely available for redistribution 